\title{
Does Community-based Forestry Management Approach Improve the Livelihoods of Local People? A Case of Sal-forest area in Bangladesh
}

\author{
Mohammad Golam Farouque \\ JSPS Invitation Research Fellow, Laboratory of International Development Studies \\ Graduate School of Agricultural Science. Tohoku University, Japan \\ Katsuhito Fuyuki \\ Associate Professor, Laboratory of International Development Studies \\ Graduate School of Agricultural Science, Tohoku University, Japan \\ Nina Takashino \\ Assistant Professor, Laboratory of International Development Studies \\ Graduate School of Agricultural Science, Tohoku University, Japan
}

\begin{abstract}
Community-based forest management (CBFM) approach has been implementing in the degraded Sal forest areas since 1989 with an aim to eliminate the main causes of forest depletion as well as alleviate poverty through participation of local people who depend on forest for their livelihoods in Bangladesh. The objective of the study was to explore the impact of CBFM initiative on the livelihoods of local people based on empirical data collected from the CBFM project sites. The study was conducted in two forest ranges of Sakhipur Sal forest area under Tangail district of Bangladesh. The findings indicate that though CFFM initiatives improved the financial capital of respondents to an extent, other livelihood capitals faced constraints and difficulties. Biasness of the CBFM project personnel and social discrimination, inequality issues and social capital differences were emerged between ethnic and non ethic respondents.. Lack of concrete commitment by the CBFM project personnel in particular and forest department in general, CBFM could not fulfill the demands of local people and limited success had been created to improve the overall livelihoods situation. It was reported during field observation that CBFM approach alone was not sufficient to manage and conserve the Sal forests or ensures local people's basic needs and demands. Therefore, to address the diversified needs of forest dependent local people and to manage and conserve Sal forest in a more sustainable way, the forest department of Bangladesh might initiate a long-term-integrated approach with skilled local forest staff.
\end{abstract}

Key Words: Community-based forest management, Livelihood, Local people, Sal forest, Bangladesh

\section{INTRODUCTION}

Management and conservation practitioners throughout the world continue to seek viable alternatives to strict protectionism, and it is increasingly argued that projects must achieve not only ecological but also economic, and social goals. Since the 1980s, conservation efforts in developing countries have generally tried to incorporate the interests and views of local people with an approach often referred to as community-based forest management (CBFM) approach. It typically aims to combine elements that link management and conservation with development, engage local communities as active stakeholders, and/or devolve control over natural resources (Horwich and Lyon, 2007). The shared rationale is that promoting socio- 
economic benefits, either directly or by compensating the costs associated with management and conservation, is important in both its own right, and as a key strategy for slowing deforestation and protecting endangered habitats and species.

Over the last three decades, many natural resource management activities have been undertaken in different parts of the world especially in developing countries like Bangladesh with the hope that they will simultaneously address the problem of declining rural livelihoods and resource degradation (Sharma, 2006; Tyler, 2006).

Table 1: Historical development of community-based forestry in Bangladesh

\begin{tabular}{llr}
\hline & Programmes & Period \\
1. & Forestry Extension Service Phase - I & $1962-1963$ \\
2. & Hetagi-Pomra community Forestry Project & $1979-1980$ \\
3. & Jhumia Rehabilitation Programme in CHT Phase - 1 & $1979-1989$ \\
4. & Development of Forest Extension Service Phase -II & $1980-1985$ \\
5. & Community Forestry Project & $1982-1987$ \\
6. & Afforestation and Nursery Development Project & $1987-1995$ \\
7. & Jhumia Rehabilitation Programme in CHT Phase -1 & $1990-1995$ \\
8. & Participatory Social Afforestation & $1991-1998$ \\
9. & Forest Resource Management Project: Forest Directorate Component & $1992-2001$ \\
10. & Extended Social Forestry Project & $1995-1997$ \\
11. & Coastal Project & $1995-2000$ \\
12. & Forestry Sector Project & $1997-2004$ \\
13. & Sundarban Biodiversity Conservation Project & $1999-2006$ \\
14. & Nishorgo Support project & $1999-2008$ \\
15. & Char Development and Settlement project - II (2nd Phase) & $2005-2010$ \\
16. & Reedland Integrated Social Forestry Project & $2005-2010$ \\
17. & Afforestation in the Denuded Hill Areas of Diversity (2nd Phase) \\
18. & Biodiversity Conservation and Poverty Alleviation through Afforestation & $2008-2012$ \\
& in the Greater Rajshahi and Kushtia Districts & $2008-2012$ \\
19. & Participatory Social and Extension Forestry in Chittagong Hill Tracts \\
20. & Community based Adaptation to Climate Change through Coastal \\
& Afforestation & $2008-2012$ \\
21. & Revegetation of Madhupur Forest through Rehabilitation of Depended & $2009-2012$ \\
& and ethnic Communities & \\
22. & Poverty Alleviation through Social Forestry & $2010-2012$ \\
\hline
\end{tabular}

\section{Source: BFD, 2016}

In Bangladesh, forest extension activities were launched in 1962-63 with the establishment of two forest extension divisions- first at Dhaka and Rajshahi and later Comilla and Jessore. Extension activities were primarily confined to establishing nurseries in the district headquarters to raise and sell seedlings to individuals and organizations in urban areas. Since 1982 the Forest Department has successfully implemented some community forestry programmes and other are in development (Table 1). While traditional forest management resulted in a net loss of forest cover, social forestry is playing a vital role in the expansion of forest cover while benefitting thousands of people (Muhammad et al, 2005). 
However, many forest resource management regimes have tended to focus more on conservation than on helping to sustain rural livelihoods of forest-dependent people. Community-based forest management (CBFM) approach in the degraded Sal forests area have been considered as top priority by the forest department of Bangladesh since 1989. This is because of the fact that when compared to other forest of Bangladesh, the plain land and Sal forests are considered to be of more environmental and economic importance (Safa, 2004; Alam et al, 2008); in addition, they are surrounded by a high-density population. This is in turn caused the exploitation of the Sal forests to take place at an alarming rate, which brought it to close extinction. However, the importance of integrating the needs and livelihoods of local communities with biodiversity conservation efforts is now widely recognized as a key element for sustainable conservation solutions. The policy mechanisms through which to achieve this integration, however, have rarely been tested and remain poorly understood.

CBFM has been initiated to meet local populations' forest product needs, reserve ecological degradation and improve socio-economic conditions of people living near the forest area (FAO, 2015). The basic principal of CBFM approach is integration of local people in reforestation activities with multiple objectives that include ecological, economic and social benefits (BFD, 2016). The key components of CBFM approach implemented in Bangladesh include establishment of woodlot plantations, agroforestry productions, and strip plantations along road sides, village reforestation, institutional planting and seedling distribution, establishment of plantation center and training of various stakeholders involved to practice this approach. Major objectives include: increase timber production; poverty reduction; and enhance the institutional capacity of forest department (BFD, 2016). Forest-dependent local people and indigenous communities are the major stakeholders of the CBFM approach.

Since the inception of CBFM in 1989 in degraded Sal forest area, still today it is treated as one of the important projects of the donor and government imposed programmes for forest management. So far the impact of such programmes on the livelihoods of the participants is not clear (Bandyopadhayay and Shyamsundar, 2008). Research is thus needed to analyze the various aspects of this forest resource management approach especially giving emphasis on livelihood issues of project participants. Therefore, the study evaluates whether CBFM approach improves the livelihoods of local people (both ethnic and non-ethnic) or not and with what effect. It also examines how the improvements in their livelihoods might differ between these two categories of respondents.

\section{Theoretical Framework of the Study}

For maintaining tropical forests and for conserving their functions, structure and biodiversity as a collective good of humankind, forests need to be managed in a sustainable way. These efforts are faced with the threefold task of incorporating ecological, economic and social sustainability aspects equally into development approaches. The relevance of livelihood issues to sustainable forest management has its basis in the United Nations Conference on Environment and Development 1992 and is at present an essential element in developing approaches (Caplow et al, 2011; Angelsen et al, 20011, Evans and Gauriguata, 2008). In order to assess the impact of community-based forest management (CBFM) approach upon the livelihoods of local people, this study used livelihood system model. Carney (1998) presents a definition of livelihoods based on the work of Robert Chambers and Gordon Conway:

"A livelihood comprises the capabilities, assets (including both material and social resources) and alternatives requires for a means of living. A livelihood is sustainable when it can cope with and recover from stresses and shocks and maintain or enhance 
its capabilities and assets both now and in the future, while not undermining the natural resource base" (Carney, 1998).

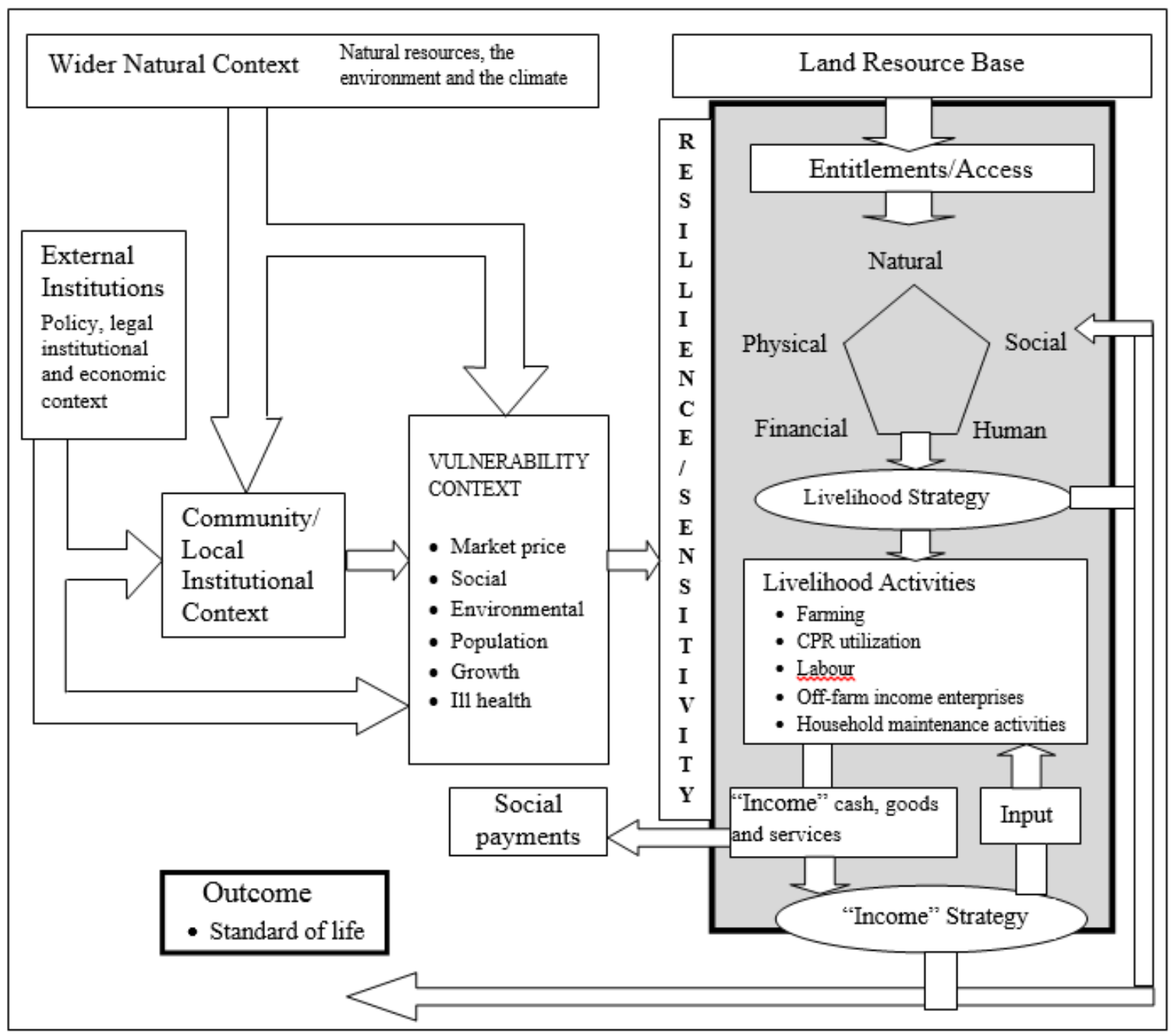

Figure 1: Livelihood Systems Model (Soussan et al, 2001)

A number of livelihood systems models have recently emerged that present household livelihood processes and functions. The model used in this paper has been developed by Soussan et al, (2001) (Figure 1). Households build their livelihoods on the basis of their assets and available opportunities. Household 'livelihood assets' are augmented through 'entitlements' to locally available capital, such as tree and forest resources. Different households within the same locale have diverse levels of household assets. The poorest may have to rely simply on their own human capital and entitlement to common properties. Households arrive at a 'livelihood strategy' on the basis of assets available, in view of opportunities arising, level of resource access, risk aversion and perceived benefits. On the basis they then engage in 'livelihood activities'. This model gives an understanding of households' livelihood processes, and allows one to 'map' the consequences of specific changes, including changes brought about through external interventions intended to improve people's lives. The main livelihood activity for most of the households in the study areas is agriculture. For households with little or no agricultural land, the main occupation open are local manual work as agricultural labourers or porters, and artisanal production (with skills and tools passed inter-generationally within households). Collecting forestry products can be an important supporting activity for such households, since non agricultural livelihoods are 
particularly vulnerable to seasonal fluctuations in demand. Changes in the entitlements/access conditions can vitally affect their livelihoods, as can changes the conditions of resources.

This livelihood framework looks at the basic dynamics of livelihoods and how people are represented on a set of capital/assets as a basis for their livelihoods (Carney, 1998; Hussein and Nelson, 1998). The framework is also useful for explaining the interrelationships among different livelihood capitals and their utilization in diversifying livelihood strategies to attain desirable outcomes in the available enabling environment. In the livelihood framework, these assets are represented by human capital (skill, knowledge, capacity, labour ability and good health), social capital (relationship of trust and reciprocity, networks and memberships of groups), physical capital (basic infrastructure, transport, shelter and communications), natural capital (land, forest, water, wildlife and biodiversity) and financial capital (monetary resources- savings, credit, remittances etc.). The assets are the livelihood building blocks and a range of assets are needed to attain positive livelihood outcomes (Warner, 2003).

However, in Bangladesh CBFM has been contributing to the livelihoods of forest-dependent people mainly by improving different livelihood assets/capital. In assessing the livelihood status of the local people, improvement in all of the five capitals could be termed as strong sustainable livelihood, whereas improvement in only some of the capitals that compensate for any decline in other capitals could be termed as poor sustainable livelihood (Das, 2009). This study analyses the base assets of the participants and explores their access to livelihood assets in the CBFM approach.

\section{Study Area}

\section{METHODOLOGY}

In Bangladesh, Sal forest belongs to the category, 'Tropical Moist Deciduous Forest' dominated by a single plant species, commonly known as Sal tree (Shorea robusta), which is one of the most important time yielding plants. The distribution of Sal forest is controlled by the conditions of topography, geology, and soil. These type of forests cover an area of 121,000 ha which is about $32 \%$ of the total forest land in Bangladesh (BBS, 2014), which is distributed over the relatively drier central and north-western part of the country (Fig. 2). The major Sal forest lies in the districts of Tangail, Mymensingh, Gazipur and Dhaka. Among these districts, Sal forest in Tangail district is the largest belt, distributed between the Brahmaputra and the Jamuna rivers extending a length of $96 \mathrm{~km}$ and width of 8 to $24 \mathrm{~km}$ running from north to south (GOB, 2015). However, in 1989, Asian Development Bank (ADB) started participatory forestry project mainly with Madhupur and Sakhipur Sal forests areas in Tangail district. Presently, it is called as community-based forest management (CBFM) approach. Sakhipur Sal forest is located in the south-eastern part of Tangail Forest Division with a small portion of the boundary with the Mymensingh Forest Division. Therefore, this study has been conducted in Sakhipur Sal forest area consists of two ranges (forest administrative unit) namely, Hoteya and Baheratoli where woodlot plantation and agroforestry activities were implemented under the direct supervision of CBFM project personnel. 


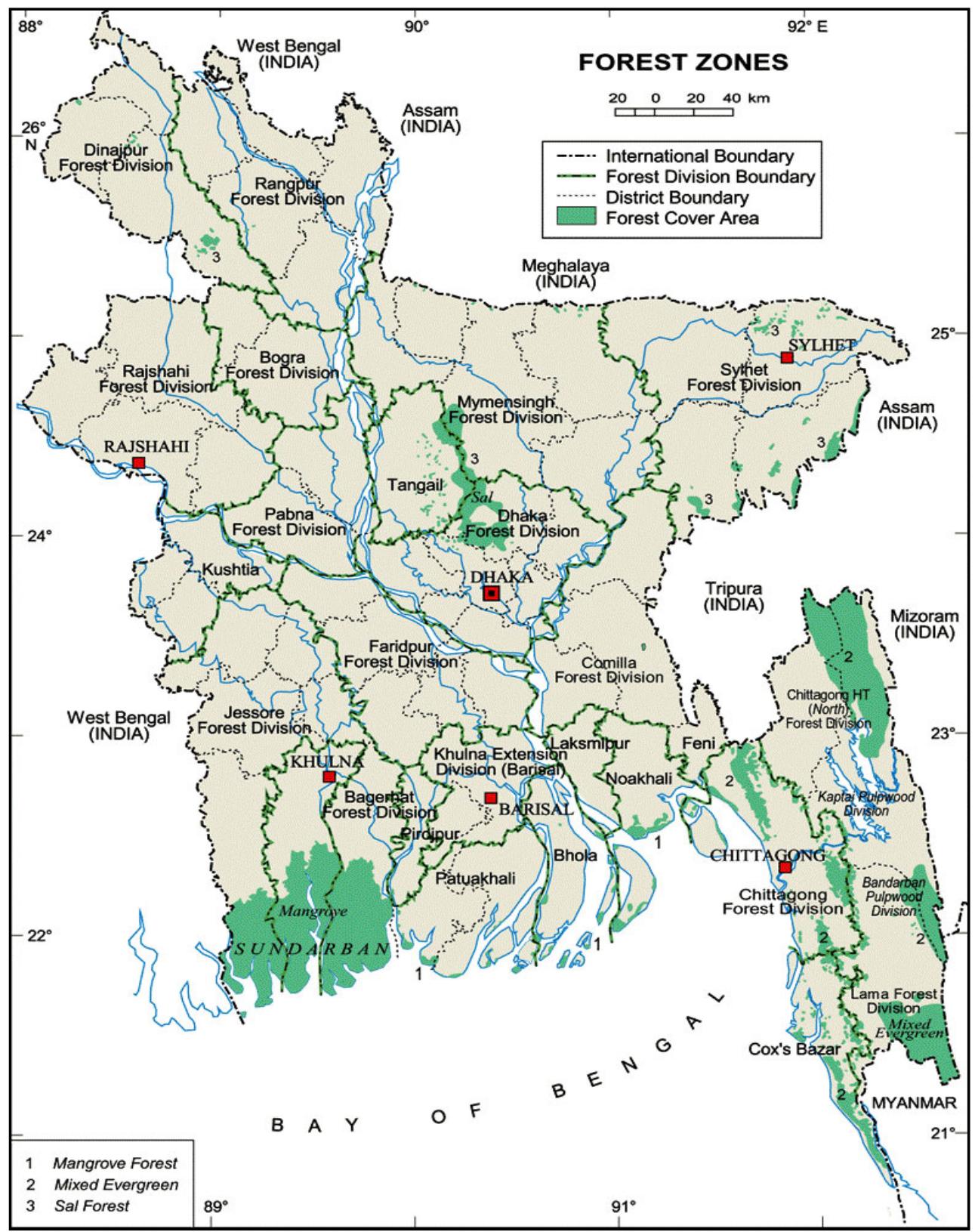

Figure 2: Forest cover of Bangladesh (Source: BFD, 1999) along with indicating study area a brief description about woodlot plantation programme

Under this programme, each participant is allocated 1 ha of degraded forest land for woodlot cultivation lasting for one 10-year cycle. The fast-growing fuel wood species such as Acacia auriculiformis and A. mangium are used for plantation with a spacing of $2 \mathrm{~m} \times 2 \mathrm{~m}$ (total 2500 trees ha-1). After 4 years, $50 \%$ of the standing trees are thinned out (first thinning) and this process was repeated after 7 years (second thinning). The Forest Department and participants share the benefits of the second thinning and the final tree harvest outputs at a ratio of $45 \%$ and $45 \%$, with the remaining $10 \%$ benefit reserved for the future through the allocation of the Tree Farming Fund (BFD, 2016). In addition, the participants can grow crops alongside the trees at any time during the cycle and the benefits gained from these crops, together with first tree thinning outputs, are granted solely to the participants. 


\section{A brief description about agroforestry plantation programme}

Each participant is allocated 1 ha of degraded forest land where they utilize the agroforestry model under the agroforestry plantation programme. Here alternating space is provided for trees and agricultural crops. The first $4 \mathrm{~m}$ were for trees (selected by the forest department) and three rows were planted with a spacing of $2 \mathrm{~m} \times 2 \mathrm{~m}$. The next $20 \mathrm{~m}$ are allocated for agricultural crops. The patterns of trees and agricultural crops are repeated until the agroforestry plot is filled. An estimated 750 trees ha- 1 are planted in this process and a 50\% thinning operation is only implemented in the seventh year of the cycle. As before, all crop benefits belong to the participants (BFD, 2016). The available evidence reports that the crop production is a bit higher in the agroforestry programme than that of the woodlot programme.

\section{Data collection and analysis}

For the study, both primary and secondary data were collected those were quantitative and qualitative in nature. Primary data was collected by semi-structured interview schedule using face-to-face interview method with the heads those were mostly quantitative in nature. Qualitative data, on the other hand, was collected through interviews, focus group discussions, and discussion with forest CBFM project personnel. For secondary data, literature review and personal observation were mostly used. The study purposively selected 80 households (36 ethnic and 44 non-ethnic) from two forest ranges, namely, Hoteya and Boheratoli under Sakhipur Upazila of Tangail district in Bangladesh (Table 2). A pre-test was conducted to check the quality of the questionnaire and modifications were done based on the experience of the test. The questions were designed to collect data on the five capitals (human, social, physical, natural and financial) possessed by the respondents based on the sustainable livelihood framework.

Table 2: Total number of household and the number of sampled in each village

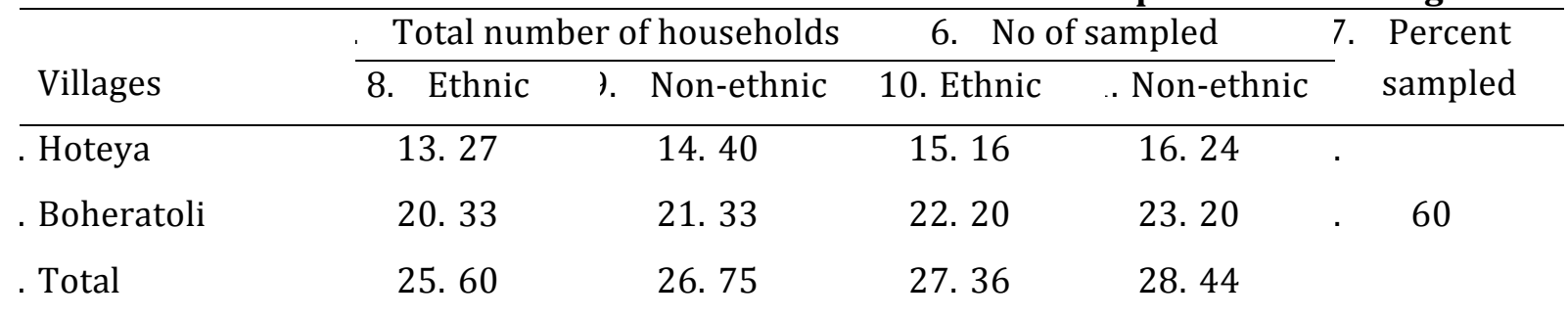

The same questionnaires were employed for both categories (ethnic and non-ethnic) of respondents and interviews were carried out during January to February 2016 with the help of two enumerators. To calculate total income of each household, income from trees of CBFM project, agriculture, livestock, labour and other sources (remittance and off-farm) were considered. Three thinning and final harvest income were also included on a yearly basis. A five-point Likert type scale (Allen and Seaman, 2007) was used to measure the social capital variable and vulnerability context of the respondents. The SPSS version 20 was used to analyze the quantitative data collected for this study.

\section{Characteristics of the selected sample}

\section{RESULTS AND DISCUSSION}

During the field study, 36 household heads of ethnic (45\%) and 44 household heads of nonethnic families (55\%) were interviewed (Table 3). The mean ages of the ethnic and non-ethnic respondents were 50 and 52 years, respectively. In case of level of education, the average education level of ethic respondents was 5.78 and it was 6.02 for non-ethnic respondents. The finding shows that the level of education was a bit higher for the non-ethnic respondents than 
those of ethnic ones. Data concerning duration of involvement with CBFM project indicates that the ethnic and non-ethnic respondents were 5.61 and 7.49 years of involvement with CBFM projects, respectively. The average family income of ethic respondents was 163.99 thousand BD Tk which was a bit lower than the average family income of non-ethnic respondents (175.59 thousand BD Tk). The rate of credit received had a bit higher for nonethnic respondents $(68.2 \%)$ than that of ethnic respondents $(60.3 \%)$. Findings related to participation in training supported by the CBFM project reveal that about half of the sampled respondents under ethic category had received training, while $68.2 \%$ of the respondents from non-ethnic category received training. The majority of the ethnic respondents $(62 \%)$ did not have membership in any local formal committee (s). On the contrary, a significant proportion of ethnic respondents (60\%) were found with the membership in local formal committee (s) in the study areas. The mean values of knowledge of ethnic and non-ethnic respondents on forest conservation were 4.48 and 4.96 , respectively.

Table 3: Salient features of personal and demographic characteristics of the respondents

\begin{tabular}{lcc}
\hline Selected characteristics & 30. Ethnic & . Non-ethnic \\
\hline . Age (year) & $33.50 .04 \pm 7.78$ & $34.52 .00 \pm 7.91$ \\
. Education (year of schooling) & $36.5 .78 \pm 3.58$ & $37.6 .02 \pm 3.09$ \\
. Duration of involvement with CBFM project (year) & $39.5 .61 \pm 4.40$ & $40.7 .49 \pm 4.60$ \\
. Family income ('000' BD Tk) (1 US\$ = 78 BD Tk) & $2.163 .99 \pm 92.14$ & $13.175 .59 \pm 101.65$ \\
. Credit received & 45. & 46. \\
47. Yes & $48.60 .30 \%$ & $49.68 .20 \%$ \\
50. No & $51.39 .70 \%$ & $52.31 .80 \%$ \\
. Participation in training supported by CBFM project & 54. & 55. \\
56. Yes & $57.49 .12 \%$ & $58.68 .20 \%$ \\
59. No & $60.50 .88 \%$ & $61.31 .80 \%$ \\
. Membership in local formal committee (s) & 63. & 64. \\
65. Yes & $66.38 .81 \%$ & $67.60 .17 \%$ \\
68. No & $69.61 .19 \%$ & $70.49 .83 \%$ \\
. Knowledge on forest conservation (scale score:0-8) & $72.4 .48 \pm 1.13$ & $73.4 .96 \pm 1.61$ \\
\hline
\end{tabular}

\section{Livelihood Capitals}

The livelihoods approach seeks to gain an understanding and realistic understanding of people's strengths (assets or capital endowments) and how they endeavor to convert these into positive livelihood outcomes. In the study areas, since the respondents of this research were involved in the CBFM project activities, they were able to build up several types of livelihood capitals. This study examined some important variables of the capitals based on livelihood framework.

\section{Human Capital}

Human capital represents the skills, knowledge, and ability to labour and good health that together enable people to pursue different livelihood strategies and achieve their livelihood objectives. At a household level, human capital is a factor of the amount and quality of labour available; this varies according to household size, skill levels, leadership potentials, health status etc. It is considered as a building block or means of achieving livelihood outcomes. As well as being of intrinsic value, human capital is required in order to make use of any of the four other types of assets (DFID, 2001). 
Data in Table 4 represents the status of human capital of the respondents in the study areas. In case of literacy rate, it was found that the literacy rate was higher for non-ethnic respondents than ethnic respondents. This may be because of easy access and availability of educational institutes to the non-ethnic respondents compare to ethic ones in the study areas. A number of training sessions (3-5 days), workshops, discussions meetings and field visit were conducted at local level with the aim of increasing the level of awareness and skills for participants and these were the initiatives to build human capital. Finding related to reception of training by the respondents showed that $73.32 \%$ of the non-ethnic respondents received training, while $53.11 \%$ of the ethnic respondents received training.

Table 4: Respondents' status of human capital

\begin{tabular}{lcc}
\hline Components of human capital & \multicolumn{2}{c}{ Respondents } \\
\cline { 2 - 3 } & Ethnic & Non-ethnic \\
\hline Literacy rate (\%) & 32.75 & 43.11 \\
Training received (\%) & 53.11 & 72.32 \\
Participation in forest management and & 46.12 & 67.09 \\
$\begin{array}{l}\text { conservation workshop and discussion meeting (\%) } \\
\text { Availability of labour (15-50 yrs) in each } \\
\text { household (mean } \pm \text { SD) }\end{array}$ & $1.76 \pm 0.74$ & $1.78 \pm 0.71$ \\
\hline
\end{tabular}

The extent of participation in forest management and conversation workshop and discussion meeting was also a bit higher for non-ethnic respondents compare to ethnic respondents. This may be because of some sort of biasness of CBFM project personnel to non-ethnic communities. The ethnic respondents in the study areas also mentioned similarly during focus group discussion. However, training, workshop and discussion meeting help participants enhance their knowledge and skills related to forest management, community development, organizational and leadership capacity developments which, in turn affect the social capital. Islam et al, (2010) reported that the respondents who had received or joined full training, they could manage CBFM activities more efficiently that those with no training.

Though the number of available labours in ethnic and non-ethnic respondents' household was almost similar, the income of non-ethnic households' respondents from labour sources was higher than ethnic ones (Figure 3). This was because of the fact that ethnic people often faced social discrimination in the society. Gain (2002) also reported similarly in his study. The government health programmes mostly have better coverage in urban areas than that of rural areas in Bangladesh. Hence, the poor populations living in rural areas usually have limited access to health services. It was true in CBFM areas and it was observed that the situation of the non-ethnic communities was somehow better than that of ethnic ones.

\section{Social Capital}

Social capital refers to a network of mutual support that exists within and between households, extended family, and communities, which people can utilize to gain, for example, loans, child care, food, accommodation and information about employment and opportunities (Dersham and Gzirishvili, 1998; Moser, 1998). The aspects of social capital such as networks and connectedness, membership of formalized groups, and relationships and trust, reciprocity and exchange, all are inter-related which are viable and critical resources for poor people, especially time of social crisis and socio-cultural changes as well. Of all the five livelihoods building blocks, social capital is the most intimately connected to transforming structures and processes (DFID, 2001). 
It was reported during field observation that CBFM project created a social platform and the participants were organized as a small social group. Since the ethnic people had been living in the same area for over a decade, they built a strong network within themselves which had a positive effect on their social capital. However, the involvement of non-ethnic respondents with social and community organizations was higher (5) than that of ethnic ones (3) (Table 5). This may be because of availability of the organizations in the locality and local people's interest to participate. The ethnic participants had to face a higher average distance $(7.13 \mathrm{~km})$ for carrying their products to the nearest market than non-ethnic respondents $(6.05 \mathrm{~km})$. A slightly negative relationship with forest department and CBFM project personnel was reported for ethnic respondents, while it was slightly positive for non-ethnic groups.

Table 5: Respondents' status of social capital

\begin{tabular}{lcc}
\hline Components of social capital & \multicolumn{2}{c}{ Respondents } \\
\cline { 2 - 3 } & Ethnic & Non-ethnic \\
\hline Involve with social and community organizations & 3 & 5 \\
(number) & & \\
Distance of market (Km; mean \pm SD) & $7.13 \pm 1.54$ & $6.05 \pm 1.21$ \\
Relationship with forest department and project & Slightly & Positive \\
personnel & negative & \\
Household food security (\%) & 27 & 46 \\
\hline
\end{tabular}

The consequence of antagonistic relationships of the ethnic respondents with forest department and CBFM project personnel had negative influence on social capital which ultimately enhance the deforestation of Sal forest and loss of natural resources. In addition, the respondents were asked about their household food security which indicated that only $27 \%$ of the ethnic respondents were found with secured with food throughout the year and rest of them suffered with food insecurity. On the other hand, $46 \%$ of the non-ethnic respondents had secured with food throughout the year. Overall this means that both categories of respondents had to suffer from food shortages and that ethnic respondents were more vulnerable to this situation compare to non-ethnic ones.

\section{Physical Capital}

Physical capital comprises the basic infrastructure and producer goods needed to support livelihoods. Infrastructure consists of changes to the physical environment that help people to meet their basic needs and to be more productive. Producer goods, on the other hand, are the tools and equipment that people use to function more productively (DFID, 2001). Moser (1998) opined that housing is one of the most important physical assets for poor households and it is used both for shelter and reproductive purposes and for productive income generating purposes as well (renting out of houses or using the space as s workshop areas).

Presently, houses made using brick-wall and tin roofs are considered as the standard home structure in the rural areas of Bangladesh. The higher proportion of ethnic respondents houses (45\%) were made with mud-walled with sun-grass roof followed by mud-walled with tin roof (32\%) (Table 6). Only 6\% of the ethnic respondents had houses made with brick-wall and tin roof. On the contrary, $26 \%$ of the non-ethnic respondents had houses with mud-walled with sun-grass roof followed by mud-walled with tin roof (37\%) and tin walled with tin roof (21\%). Importantly, $16 \%$ of the houses of non-ethnic respondents were made with brick-wall with tin roof, thus, housing structured differed significantly between the ethnic and non-ethnic respondents in the study areas. 
Table 6: Respondents' status of physical capital

\begin{tabular}{lcc}
\hline Components of physical capital & \multicolumn{2}{c}{ Respondents } \\
\cline { 2 - 3 } & Ethnic & Non-ethnic \\
\hline Structure of household (\%) & 45 & 26 \\
$\quad$ Mud-walled and sun-grass roof & 32 & 37 \\
Mud-walled with tin-roof & 17 & 21 \\
Tin-walled with tin-roof & 6 & 16 \\
$\quad$ Brick wall with tin-roof & & \\
Road infrastructure (CBF to household & 67 & 30 \\
and market) (\%) & 23 & 49 \\
$\quad$ Muddy & 10 & 21 \\
Brick & & \\
Brick and bitumen sealed & $4.72 \pm 3.48$ & $5.13 \pm 3.62$ \\
Livestock & $2.31 \pm 2.13$ & $2.15 \pm 1.39$ \\
$\quad$ Small (mean \pm SD) &
\end{tabular}

During field survey, it was reported that the possession of electronic devices (e.g. CD players, television, refrigerator etc.) and other home appliances were higher for non-ethnic respondents' households than ethic households which, in turn indicated that non-ethnic respondents enjoy a higher status of living than ethnic ones. In addition, ethnic respondents had to face mostly muddy and partly brick bitumen sealed road structures to transport their products to market. The non-ethnic respondents, on the other hand, used mostly brick and bitumen sealed road structures (Table 6). Due to poor road infrastructure facilities, ethnic respondents had to pay more extra costs for carrying their goods to the main market than ethic respondents did, which ultimately affect the financial capital badly.

Findings concerning livestock possession of the respondents' households showed that the average number of small-sized livestock such as- chickens and ducks was higher for non-ethnic respondents (5.13) than ethnic respondents (4.72). Most of the ethnic households had 2.31pigs (on average) as large livestock that they could sell in a time of family crisis to earn between 15,000 to $25,000 \mathrm{BD} \mathrm{Tk}$ ( $1 \mathrm{US} \$=80 \mathrm{BD} \mathrm{Tk}$ ). About $86 \%$ of the ethnic respondents stated that they bought piglets after receiving CBFM benefit/money or credit received from CBFM project. Nearly $71 \%$ of the non-ethnic respondents, on the other hand, had at least two large animals such as-goats and cows on which they could rely for their daily milk consumption, drafting plough and some additional income from selling the excess. About half of the non-ethnic respondents mentioned that they bought a calf of big cattle (cow/bull) after getting money from CBFM benefit or credit received from CBFM project.

\section{Natural capital}

Natural capital is made up of the natural resource stocks from resource flows useful to livelihoods, including land, water and other environmental resources (Carney, 1998; DFID, 2001). The natural resources on which the rural poor most depend may, because of their lack of access to private assets, be common pool resources. Thus, clearly, natural capital is very important to those who derive all or part of their livelihoods from resource-based activities (farming, fishing, gathering in forests, mineral extraction etc.). The relationship between natural capital and the vulnerability context is particularly close. Many of the stocks that devastate the livelihoods of the poor are themselves natural processes that destroy natural capital (e.g. fires that destroy forests; floods and earthquakes that destroy agricultural land) and seasonality is largely due to changes in the value or productivity of natural capital over the year. 
Table 7: Respondents' status of physical capital

\begin{tabular}{lcc}
\hline Components of natural capital & \multicolumn{2}{c}{ Respondents } \\
\cline { 2 - 3 } & Ethnic & Non-ethnic \\
\hline Family landholdings (hac; mean \pm SD) & $0.463 \pm 0.124$ & $0.558 \pm 0.237$ \\
Tree stcok in CBF (mean \pm SD) & $395 \pm 127.41$ & $429 \pm 107.18$ \\
Number of trees in household area (mean \pm SD) & $14.29 \pm 3.15$ & $13.72 \pm 4.09$ \\
Forest-dependency & Moderate to highly & Moderately \\
\hline
\end{tabular}

Land is an important natural capital and the average family land holdings of the ethnic and non-ethnic respondents were 0.463 ha and 0.558 ha, respectively (Table 7), means that they do not have sufficient cultivable lands to produce agricultural crops. On average, the ethnic respondents had 395 fast-growing fuel wood trees, whereas, the non-ethnic respondents had 429. Data concerning number of trees in household area showed that the ethnic respondents had a bit higher number of trees compare to non-ethnic respondents. This study reported that the ethnic population depended on forest resources to the extent of moderate to heavy, while the non-ethnic respondents had moderately. Though the ethnic people traditionally conducted Jhum cultivation (a system of cultivation involves clearing a piece of land by setting fire or clear felling and using the area for growing crops of agricultural importance such as upland rice, vegetables or fruits usually practiced by the tribal groups), presently they have stopped it due to lack of free/bare forest areas as CBFM restricted easy access to Sal forests. As a result, they shifted from Jhum cultivation to encroachment of Sal forests (Gain, 2002), or involved in CBFM project and other projects run by GOs and NGOs. During a discussion meeting with CBFM project personnel, it was reported that some ethnic participants claimed CBFM land as their own property and declared that they could not back the land right/tenure to the forest department. Though it was anticipated initially that the CBFM project might be helpful in resolving land tenure issue, the reality turned out to be different.

\section{Financial Capital}

Financial capital denoted the financial resources that people use to achieve the livelihood objectives. Income from the sale of labour is often one of the most important financial assets of rural poor. There are two main sources of financial capital; i) available stocks such as cash, bank deposits or liquid assets such as livestock and jewellery; and ii) regular inflows of money such as pension, remittance and sale labour (DFID, 2001). Financial capital is probably the most versatile of the five categories of assets because it can be converted with varying degrees of ease, depending upon transforming structure and process into other types of capitals. In addition, it can be used for direct achievement of livelihood outcomes- for example, when food is purchased to reduce food insecurity.

Table 8: Respondents' status of physical capital

\begin{tabular}{lcc}
\hline Components of financial capital & \multicolumn{2}{c}{ Respondents } \\
\cline { 2 - 3 } Easy loan facilities (\%) & Ethnic & 53 \\
CBFM project & 37 & 59 \\
Different credit organizations/institutions & 45 & 51 \\
Sources of annual income (\% of total income) & 43 & 16 \\
CBF & 15 & 11 \\
Agriculture & 14 & 8 \\
Livestock & 11 & 10 \\
Remittance & 7 & 4 \\
Labour & 10 & 86.15 \\
Others & 98.03 & \\
Annual expenditure (\% of total income) & & \\
\hline
\end{tabular}


For different purposes such as seasonal crop cultivation, raising livestock, repairing homes, marriage affairs or in case of illness of family members, the respondents (both ethnic and nonethnic) needed credit support which was mostly managed by taking loans. Only $37 \%$ of the ethnic respondents had been able to take loans from CBFM project, while $53 \%$ of the nonethnic respondents had been able to (Table 8 ). It was observed that $45 \%$ of the ethnic respondents could manage loans easily form different organizations/institutions, whereas $59 \%$ of the non-ethnic respondents could manage loans from the same credit organizations/institutions. Loans from relatives were usually interest free but it was rare for both categories of respondents, while loans from NGOs and other sources included at least 10 $\%$ interest rate.

Though both categories of respondents in the study area had diversified sources of income, it was observed that the main source of their income was CBFM income and it covered $43 \%$ and $51 \%$ of total income for ethnic and non-ethnic respondents, respectively. It was also observed that though the income from agriculture was mostly equal for both categories of respondents, income from livestock and remittance was a bit higher for ethnic respondents than non-ethnic ones. Although the family income from labour source is a bit higher for non-respondents than ethnic ones, it was also observed that CBFM created some labour opportunities for both categories of respondents. However, the ethnic respondents were not able to manage any savings, whereas non-ethnic respondents were able to manage about $14 \%$ average saving of their annual income.

\section{Vulnerability Context}

Vulnerability is a hypothetical and probability-related context (Blaikie et al, 1994) and is an integral part of livelihood framework. The vulnerability context refers to the seasonality, trends and shocks that affect people's livelihoods. Respondents' livelihoods and the availability of capitals are mostly affected by the vulnerability context i.e. the external factors. The key attribute of these external factors is that they are not susceptible to control by local people themselves. These external factors are important because they have a direct impact on each participant's capital/assets status (DFID, 2001). It is, therefore, important to identify indirect means by which the negative effect of the vulnerability context can be minimized- including building greater resilience and improving overall livelihood security.

The ability to recover from shocks is an important element in assessing vulnerability. Since Sal forest area is gradually shrinking, it has placed an additional pressure on the livelihoods of local forest-dependent people in Bangladesh. It was reported from the field observation that soil fertility of the study area was also in declining trend. The probable reasons behind this may be over-exploitation of resources, improper cultivation techniques, irrational selection of crops, improper rotation of tree-crop associations, use of low level of organic manure etc. Although flood occurs every year in Bangladesh, the respondents informed that they were not severely affected by flood due to a good land elevation. They also stated that there was no severe damage occurred by cyclones for over few years except some minimum scale of damage of CBFM project trees and houses.

The respondents opined that the frequency of crop diseases, attack of insects and pests were increased in the study area. Both ethnic and non-ethnic respondents reported that their livestock such as goats and cows were facing more diseases than before. Although both categories of respondents stated the problems of project trees being stolen by thieves and damaged intentionally by the local rival farmers, the ethnic participants were mostly affected compared to non-ethnic ones and it has also affect their livelihood capitals. Furthermore, as 
social conflict in an important indicator to assess the impact of CBFM, this study found that participants' social capital was severely affected by the frequently occurring conflicts, and the ethnic participants experienced increases vulnerability because of conflict with the personnel of forest department and other surrounding communities as well.

\section{Livelihood Outcomes}

Livelihood outcomes are what participants are seeking to achieve through their livelihood strategies, such as financial income. They are likely to vary according to place, time, context and individual. This makes them extremely complex. These outcomes demonstrate the output of the current relationship of factors within the livelihood framework. Livelihood outcomes directly affect the participants' assets and vigorously affect their level on the Sustainable Livelihood Framework (DFID, 2001).

However, unless we conquer the complexity, and gain an understanding of what it is that people are aiming for, we will never be able to develop a meaningful understanding of livelihoods as a whole. So we took initiative to understand the outcomes of livelihoods with special emphasis on financial outcome. Figure 3 represents the different sources of income of the both ethnic and non-ethnic respondents in the study areas. The average incomes of the ethnic and non-ethnic participants were about 164 thousand BD Tk and 175 thousand BDTk (Table 3) among them income from CBF (agriculture and crop) sources was 70 thousand and 90 thousand BD TK, respectively. For both categories of respondents, the CBF outcomes were the main income sources followed by agriculture, livestock, remittance, labour and other income sources (e.g. small business.

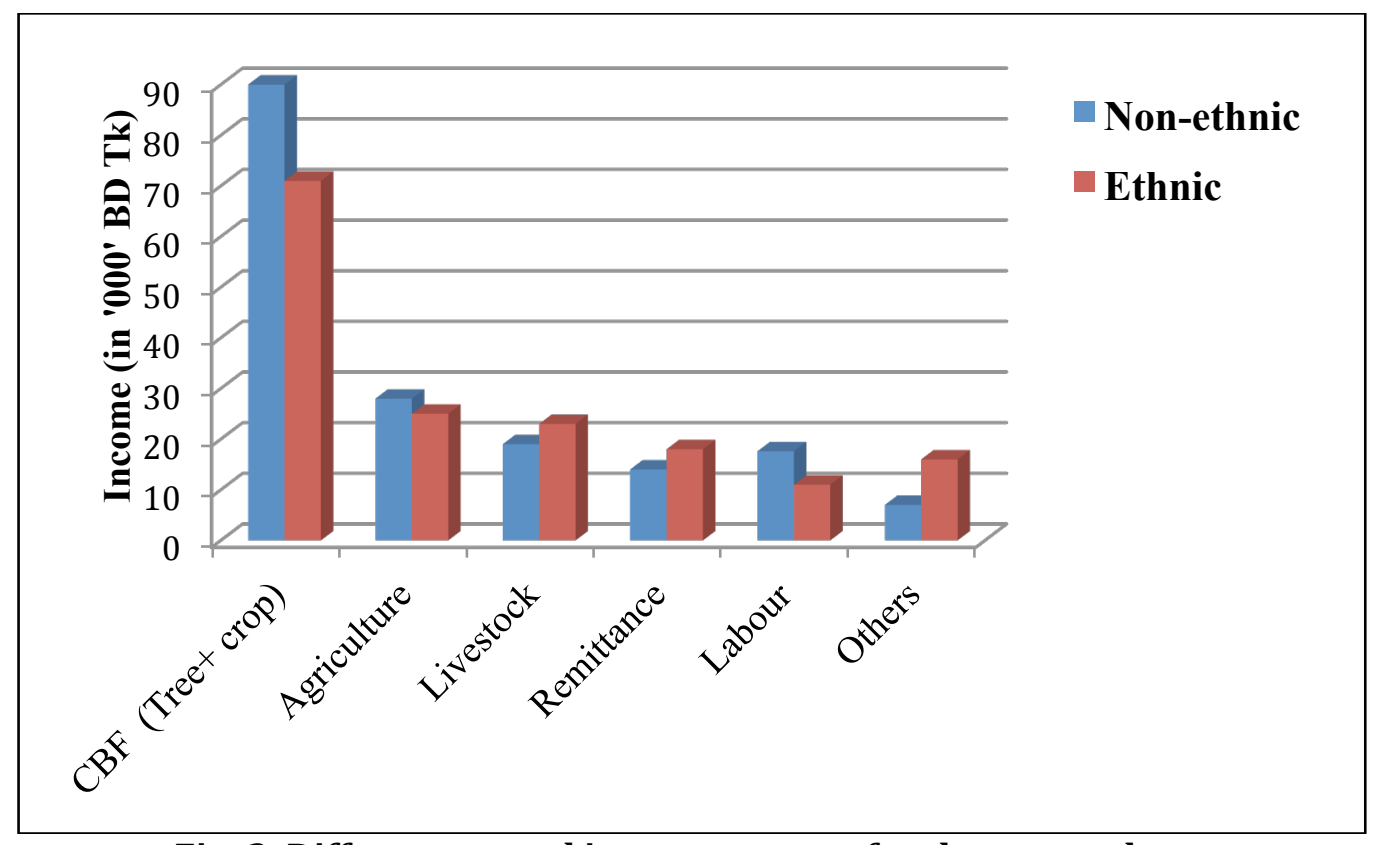

Fig: 3. Different annual income sources for the respondents

It can be summarized that the differences in participants' livelihood outcomes (income) were mainly because of CBF income variation (Beta value: 58.3 in Table 9). Islam, et al (2012) reported that income from participatory forestry programmes had a strong positive relationship with household income of the project participants. Most of the respondents in the study areas strongly opined that household income is very important not only for maintaining good living conditions but for giving tackle the adverse situations. 
Table 9: Main causes of income differences among participants

\begin{tabular}{lcccc}
\hline Variable & Beta & SE & $t$ & Significance \\
\hline Farm size & 0.168 & 0.079 & 5.13 & 0.000 \\
Family size & 0.151 & 0.056 & 4.74 & 0.000 \\
CBF income & 0.583 & 0.028 & 14.89 & 0.000 \\
Agriculture income & 0.174 & 0.084 & 5.82 & 0.000 \\
Livestock income & 0.156 & 0.088 & 4.91 & 0.000 \\
Remittance income & 0.133 & 0.081 & 3.45 & 0.000 \\
Wage income & 0.112 & 0.007 & 3.12 & 0.000 \\
Others income & 0.094 & 0.005 & 2.96 & 0.004 \\
\hline
\end{tabular}

R2 =79.85, Adjusted R2 =78.12

\section{CONCLUSIONS}

Community-based forest management (CBFM) approach has contributed in a number of ways to improve local people's livelihoods. Experience of CBFM so far has shown that the rural poverty has reduced to an extent by securing resources for the poor, increasing the availability of resources and providing potential for income generating activities. However, diverse livelihood perspectives exist within community. The relationships between the forests and livelihoods of the community members therefore vary tremendously on the basis of needs and interests. Livelihoods are simply a means of living for which resources or assets are needed. Various macro and micro level factors affect the livelihoods of community people. The capacity of the individuals and communities to increase the resources and the ability to cope with the factors of various types, the better will be the livelihoods of an individual or of a group. CBFM initiative has contributed to the improvement of local people in three ways: i) helps to increase resources; ii) fosters to reform organizations, agencies and policies to an extent; and iii) facilitate to bring social changes.

CBFM has become a means to increase the human, social, physical, natural and financial capital of local people living surrounding the Sal forest area, though all are not equally. It is concluded form the findings that among five capitals of livelihoods, CBFM has contributed more to improve the financial capital of local people than other capitals. It is also reported that CBFM initiative has increased social cohesion, which has enhanced social capital of those who have been powerless, left in isolation from mainstream social and political processes. Since the inception of the CBFM project, a number of training sessions, workshops and discussion meetings, and exposure visit have been conducted for a number of organizations and individuals related to community-based forestry that have increased knowledge and skills concerning forest silviculture, community development, organizational management and leadership development, all of which are basically human capital. Some aspects of physical and natural capitals have also been improved through CBFM project activities in the study areas. Findings of the study also concludes that the situation of non-ethnic community members related to different livelihood aspects were better than those of ethnic community members. This is because the top implementing agency, namely the forest department, did not systematically address livelihood issues with giving equal importance of both ethnic and nonethnic community members along with lack of initiative to resolve the antagonistic relationship and conflict within the participants.

Despite success stories of CBFM initiative, it faces many difficulties and challenges. In particular, working relations between local forest staff and community people, the issue of equality of providing project benefit to all categories of community members (ethnic and nonethnic), and complexity of addressing the diversified needs and interests of multiple 
stakeholders are the main challenges. A strong commitment from each stakeholder along with effective forest policy and management plan could overcome these which will protect Sal forest from gradual depletion and improve the livelihoods of people lining surrounding the Sal forest areas in Bangladesh.

\section{ACKNOWLEDGEMENT}

We thank the personnel of CFFM Project for allowing us to conduct this research work at Sakhipur sub-division of Tangail district in Bangladesh. Special thanks are due to project staff and local people who volunteered their time to be interviewed. We are grateful to the authority of Japan Society for the Promotion of Science (JSPS) for its financial support to conduct this study.

\section{References}

1. Alam, M., Y. Furukawa, S. K. Sarker \& Ahmed, R. (2008). Sustainability of Sal (Shorea robusta) forest in Bangladesh: past, present and future actions. International Forestry Review 10: 29-37.

2. Allen, E. \& Seaman, C. (2007). Likert scale and data analysis. Quality Progess, 40: 64-65.

3. Angelsen, A., Larsen, H. O. Lund, J. F. Smith-hall, C. \& Wunder, S. (2011). Measuring livelihoods and environmental dependence: methods for research and fieldwork. Edinburgh: London.

4. Bandyopadhyar, S.\& Shyamsundar, P. (2004). Fuelwood consumption and participation in community forestry in India. World Bank Policy Research Working Paper 3331. Washington, DC: The World Bank.

5. BFD, (2016). Bangladesh Forest Department, Government of the People's Republic of Bangladesh. Available at http://www.bforest.gov.bd [last accessed on 19 September 2016].

6. Blaikie, P., Cannon, T. Davis, I. \&.Wisner, B. (1994). At Risk: Natural Hazards, People’s Vulnerability and Disasters. New York, Routledge.

7. Caplow, S., Jagger, P., Lawlor, K. \& Ellis, E. (2011). Evaluating land use and livelihood impacts of early forest carbon projects: Lessons for learning about REDD+, Environmental Science and Policy, 14: 152167.

8. Carney, D. (1998). Sustainable rural livelihoods; what contribution can we make? London: Department of International Development.

9. Das, N. (2009). Can joint forest management programme sustain rural life: a livelihood analysis from community-based forest management groups> MPRA paper no 15305. Available at http://www.mpra.ub.uni-muenchen.de/15305 [accessed 20 October 2016].

10. Dersham, L. \& Gzirishvili, D. (1998). Informal social support networks and household vulnerability: empirical findings from Georgia. World Development 26: 1827-1838.

11. DFID, (2001). Sustainable livelihood Guidance Sheets: comparing development approaches. Department for International Development, London, UK.

12. Evans, K. \& Gaurigauta M. R. (2008). Participatory monitoring in tropical forest management: a review of tools, concepts and lessons learned, Bagor, Indonesia: Center ofr International Forestry Research.

13. FAO, (2015). Global Forest Resource Assessment 2015. Food and Agriculture Organizations of the United Nations, Rome, Italy.

14. Gain, P. (2002). The last forest of Bangladesh. Dhaka: Society for Environmental and Human Development.

15. Horwich, R. H. \& Lyon, J. (2007). Community conservation: practitioners' answer to critics. Oryx, 41(3):376-385.

16. Hussein, K. \& Nelson, J. (1998). Sustainable livelihood and livelihood diversification. IDS Working Paper No. 69. Brighton: Institute of Development Studies.

17. Islam, K. K. \& Sato, N. (2012). Participatory forestry in Bangladesh: has it helped to increase the livelihoods of Sal forests-dependent people? Sothern Forests, 74 (2): 89-101. 
18. Moser, C. (1998). The asset vulnerability framework: Reassessing urban poverty reduction strategies. World Development, 26: 1-19.

19. Muhammad, N., Koike, M. Sajjaduzzaman, M. \& Sophanarith, K. (2005). Reckoning Socila Forestry In Bangladesh: Policy and Plan verus implementation, Forestry, 78: 373-383.

20. Safa, M. S. (2004). The effect of participatory forest management on the livelihood of the settlers in a rehabilitation program of degraded forest in Bangladesh. Small-scale Forest Economics, Management and Policy, 3: 223-238.

21. Sharma, B. P. (2006). Poverty alleviation through forest resource management: an analysis of leasehold forestry practice in Nepal. Available at http://www.sandeeonline. com/uploads/general_docs/research_guidelines/bishnusharma.pdf [accessed 25 October 2016].

22. Soussan, J., Blaikie, P., Springate-Baginski, O. \& Chadwick, M. (2001). Understanding Livelihood Processes and Dynamics. Livelihood-Policy Relationship in South Asia Working Paper 1, University of Leeds, UK.

23. Tyler, S. D. (2006). Community based natural resource management: a research approach to rural poverty and environmental degradation. International Development Research Centre. Available at http://www.idrc.ca/en/ev-103630-201-2-DO_TOPIC.html [accessed 30 October 2016].

24. Warner, K. (2003). Moving forward: development pathways for sustainable livelihoods through forestry. In: Iddi, S., Sarrazin, K., Reeb, D. (eds), Defining the way forward: sustainable livelihoods and sustainable forest management through participatory forestry. Second International Workshop on participatory forestry in Africa, 18-22 February 2002, Arusha, United Republic of Tanzania. Rome: FAO pp 23-30. 